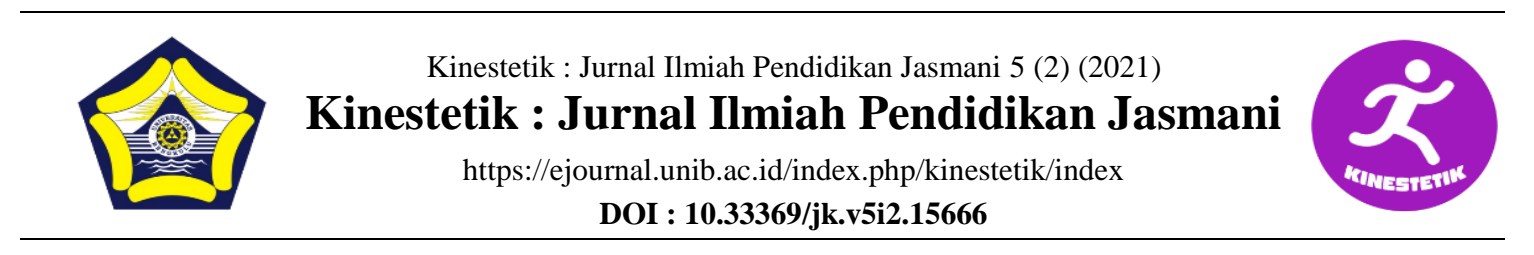

\title{
MATCH REPORT APPLICATION FOR MATCH COMMISSIONER (MC) FOOTBALL MATCH
}

\author{
Nurkadri $^{1 *}$, Argubi Silwan ${ }^{2}$, Indra Darma Sitepu ${ }^{3}$, Mawardi Nur ${ }^{4}$, Taufik Akbar $^{5}$, Rizky \\ Nursasongko Gunri ${ }^{6}$ \\ ${ }^{123456}$ Coaching Education, Faculty of Sports Science, Universitas Negeri Medan, North Sumatra, \\ Indonesia
}

\section{Article Info}

\section{Article History :}

Received : April 2021

Revised :May 2021

Accepted : June 2021

Available online : June 2021

Keywords:

Application, Report the Results, Match Comisioner (MC)

\begin{abstract}
This study aims to develop an application to report the results of Match Commissioner (MC) ASKOT PSSI Medan. Furthermore, this application is to improve the human resources of ASKOT PSSI Medan specifically for match equipment, namely MC. This research method is the development research of Budiono Saputro which adopts Borg \& Gall and Sukmadinata, then this research uses 2 (two) stages, namely stage 1 literature study, conducting literature review and needs analysis (needs questionnaire), then designing a product model and stage 2 developing and planning models do make applications, expert validation and revisions, individual trials and revisions, and group trials. The MC assessment of the application of the $\mathrm{MC}$ report results in the display aspect was $84.81 \%$ in the very good category, in the content / material aspect of $86.53 \%$ it was in the very good category, in the usage aspect it was $85.46 \%$ in the very category. good, and in the overall aspect of $85.76 \%$ it is in the very good category. It is concluded that the $\mathrm{MC}$ report application based on the assessment data of the MC ASKOT PSSI Medan city of the application developed is suitable for use with improvements according to suggestions and input, then used as the final product of this study.
\end{abstract}

\begin{tabular}{llr}
\hline Corresponding address & : Jalan Willem Iskandar / Pasar V, Medan, & ISSN 2685-6514 (Online) \\
Sumatera Utara & & ISSN 2477-331X (Print) \\
*Corresponding email & : nurkadri@ $@$ unimed.ac.id &
\end{tabular}




\section{INTRODUCTION}

The Indonesian government strives to develop in all fields in order to create a just and prosperous society, one of which is in the fields of sports and education. The development of sports has the goal of increasing physical fitness, achievement, discipline, sportsmanship, and others. Furthermore, development in the field of education aims at the quality of Human Resources (HR), namely physically and mentally healthy, skilled, broad insight, and commendable attitude and behavior. This development is an effort to maintain and improve the standard of human life by being programmed and carried out continuously (Prasetyo, 2015); (Malasari \& Juntara, 2021). Indeed, the government is currently trying to improve human resources so that it is perpendicular to what it aspires to, namely creating a just and prosperous society, especially in the fields of sports and education with short and long term planning where the ultimate goal is developed countries. In line with the improvement of human resources, the development of sports can be seen in the presence of innovations in training models, facilities and infrastructure to support human resource capabilities. This innovation is useful as a support for sports activities as the achievement of goals set both on the training side, match support and evaluation (Supriyono, 2018).

In line with the expression from the Ministry of Youth and Sports through Djoko Pekik Irianto, developed countries are carried out to improve regional and national sports achievements, namely through Mastery of Science and Technology (IPTEK), and it must be admitted that Indonesia is still lagging behind developed countries from mastery of science and technology. So in increasing the sport, science and technology has become the spearhead of developed countries (Rohmat, 2014). The conclusions from some of these references explain building a just and prosperous society as a goal that is set to become a developed country through increasing human resources in the fields of sports and education. The improvement of human resources in the sports and education fields rests on mastery of science and technology, especially in terms of facilities, infrastructure, training, competition support, evaluation and other aspects.

The world of football through FIFA has made new breakthroughs in the quality and professionalism of a competition or match, one of which is the use of VAR (video Assistant Referee) which aims to see one event that the referee does not see every match. The use of VAR was carried out for the first time at the 2018 World Cup in Russia and until now it has been carried out in European leagues, Meanwhile in Indonesia the discourse is used in the 2019 Premier League but until now PSSI has not used VAR (Bidikdot.com, 2020). The author concludes that there is a breakthrough that has been made by FIFA for the game of football, namely the development of science and technology, one of which is VAR, this is very important to see an incident that is not seen by the referee and does not rule out other breakthroughs. 
Furthermore, in chapter VIII, the general rules for the Indonesian Football Association (PSSI) explain the soccer matches being played, including match supervisors, referee inspectors and referees. The match supervisor as the supervisor of the game, the referee inspector as an evaluation of the performance of the referee and the referee has the authority and responsibility for the match, the three important components that cannot be separated from every match (Khuliman, 2018). It can be concluded that the components of the soccer match equipment consist of the $\mathrm{MC}$, the referee inspector and the referee, this component is very vital in a soccer match because this component is the standard of a soccer match. HR Medan City Association (ASKOT) PSSI Medan currently has 23 Match Commissioners (MC) as shown in table 1 below;

Table 1. Data Match Commissioner (MC) ASKOT PSSI Medan City

\begin{tabular}{llc}
\hline No & \multicolumn{1}{c}{ Category } & Total \\
\hline 1 & Region & 6 \\
\hline 2 & National & 17 \\
\hline
\end{tabular}

(source: Data Askot PSSI Medan City)

MC data 23 people who have a regional category license / certificate there are 6 people and nationally there are 17 people, of these $23 \mathrm{MCs}$ who are often assigned to Liga 1 PSSI (the highest football match in Indonesia) as many as 4 people and 19 people have never been assigned to Liga 1 PSSI at all. This condition is directly proportional to what has been done so far, namely in making the results of the match report for the MC ASKOT PSSI Medan city still manually using the MC and ASKOT PSSI Medan match report form and does not have an application that makes it easy for match reports. As revealed by Reilly \& Williams (2003) (Barreira et al., 2013) football is the most popular sport in the world, so it is one of the sources of the development of science and technology. Which is a good example of the latest research on the development of cutting-edge technology, including in the form of practical applications and web in the form of software (Supriyono, 2018). According to the authors, the development of science and technology in sports, especially in football, by developing cutting-edge technology such as the web or application which aims to store data that occurs and facilitate the implementation of soccer matches. Furthermore, the authors in this study make and develop a match report application for the MC ASKOT PSSI Medan City, North Sumatra.

With the availability of this application, it is hoped that it will make it easier for MC ASKOT PSSI Medan in making reports on local and national football game matches. Improving the human resources of ASKOT PSSI Medan, namely $\mathrm{MC}$ by using this application is able to compete at the national level in leading League 1, Liga2, Liga 3 and National Sports Week matches. It is hoped that it will also facilitate the Medan City ASKOT PSSI in organizing soccer matches in the city of Medan. This is emphasized by the expression that technology development provides integrated solutions in all related fields (Munthali, George \& Xuelian, 2020). Next, there is research by Ilya Solntsev and Nikita Osokin explaining that in Russia, the development of football is needed as a recommendation on how to better coordinate football match activities in Russia (Solntsev \& Osokin, 2018).

\section{METHODS}

This research uses development research or other terms Research \& Development (R\&D), according to Borg and Gall (1983) Sukmadinata (2008) and 
Sugiyono (2009) research methods in certain fields produce a certain product, and in together with certain additional products that have the effectiveness of a product in a concrete way, for example: education management, examples of integrated science training management model products, science education examples of integrated science material books and computer sample software (Budiono Saputro, 2017). This research has produced a product that has been tested for its effectiveness in the form of a match results report application. The purpose of this research is not to test or formulate a theory, but to develop a match result report application that is effective for use by MC ASKOT PSSI Medan and others in soccer matches in Medan.

The population of this research is MC Askot PSSI Medan, North Sumatra. The subjects of the research trials were MC ASKOT Medan, totaling 23 people. This study uses the Budiyono Saputro development design which adopts the development of Borg \& Gall and Sukmadinata. Divided into 3 stages, namely stage 1 preliminary study, stage 2 model development and planning, and stage 3 model validation (Budiyono Saputro, 2017). The steps of this research carry out 2 stages, namely a preliminary study and the development and design of the model can be seen in Figure 1 below:
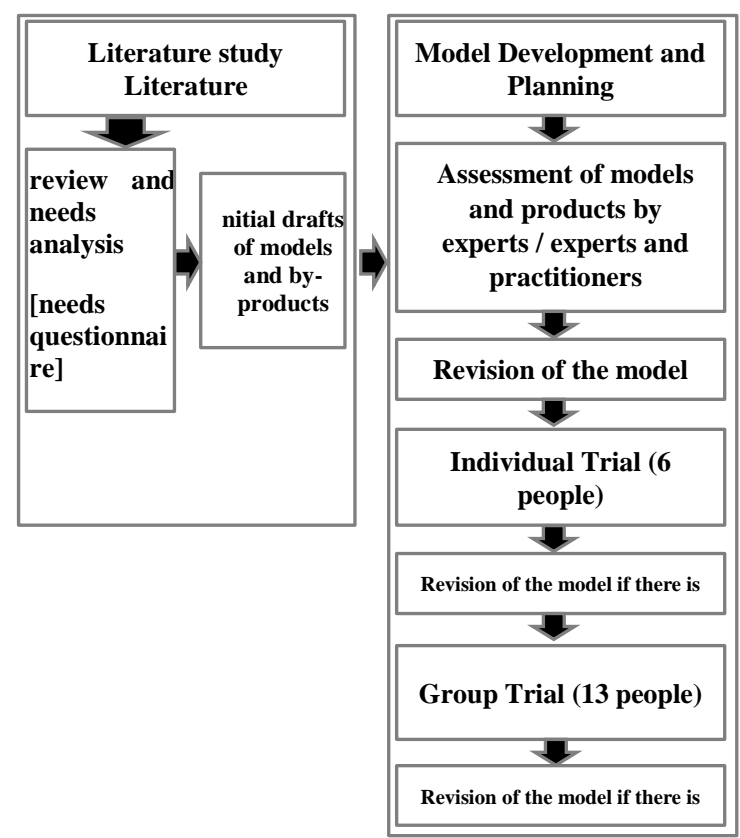

Figure 1. Model Development Procedure (Budiono Saputro, 2017)

Collecting data for this development research uses instruments that are able to explore the data needs used. The instrument used is an instrument to assess the application. This instrument is in the form of a questionnaire for material experts, media experts and MC. This research uses quantitative descriptive analysis techniques and qualitative descriptive analysis. Quantitative descriptive analysis was carried out to analyze the value scale data of the assessment results on the draft model, product assessment data, individual trial data, and group trial data. Meanwhile, qualitative descriptive analysis was carried out to explore deficiency data and input to the application before the trial and after the field trial. 
Population is a comprehensive area consisting of: objects / subjects that have certain qualities and characteristics that are determined by the researcher for study and then draw conclusions (Sugiono, 2019). The population of this research is MC Askot PSSI Medan North Sumatra, amounting to 23 people trials. A researcher is forced to be satisfied using a cluster sample because the clumps which are groups of individuals are available as units in the population, sampling in a cluster that has the same opportunity to become a sample from one population (Suryabrata, 2016). The people who tested this research were the MC ASKOT PSSI Medan city, amounting to 19 people who have regional certificates and who have never served in the PSSI League 1. For individual trials with a total of $6 \mathrm{MC}$ ASKOT PSSI Medan city, and for a group trial with a total of 13 MC ASKOT PSSI Medan city.

\section{Design or Data Analysis}

A preliminary study is carried out for data collection / needs analysis through field studies and literature studies. The analysis began with the field study of distributing questionnaires to the $\mathrm{MC}$ ASKOT PSSI Medan City which was certified Regional MC. Following are the results of a preliminary study using a survey questionnaire: $100 \%$ can operate a laptop, $82.61 \%$ have never used the MC application from PSSI, $100 \%$ of the matches held by ASKOT PSSI Medan use MC reports for smooth and professional matches, at $100 \% \mathrm{MC}$ requires a match report application, and 100\% MC agrees with the development of the match report application. So that in the future an MC match report application will be created that makes it easy and professional in the implementation of football matches.

\section{Application Design or Initial}

$$
\text { draft The initial draft design }
$$

consists of: application operational planning, menu, and expert judgment. Validation is carried out by submitting the initial product draft of the application design accompanied by an assessment sheet using a value scale in which there are input, suggestions, and revisions to experts. The results of the assessment are in the form of a scale of the truth value of the content of the material concept and media aspects of the application using a scale Likert with a choice of 5 categories. The results of an expert's assessment of the application draft are presented in table 2 below:

Table 2. Expert Validation Results Data on DraftApplication

\begin{tabular}{cccc}
\hline No & Expert & \% & Category \\
\hline 1. & Material & 82,45 & Good \\
\hline 2. & Media & 81,01 & Good \\
\hline
\end{tabular}

Table 2 shows the assessment of material experts shows a percentage of $82.45 \%$ is in the good category and the assessment of media experts shows the percentage of $81.01 \%$ is in the good category. This shows that the two experts' assessment of the application made was feasible to be developed with revisions.

\section{Product Trial Results}

Material expert assessment provides an assessment of the application being developed and provides suggestions for improvements for subsequent revision of the application. The application assessment result data is calculated from the maximum number of items and the real 
score obtained is then converted to a percentage table. The results of the material expert's assessment of the MC football match report application can be seen in table 3 below:

Table 3. Data on the Results of Material Expert Assessment of the Application.

\begin{tabular}{ccc}
\hline $\begin{array}{c}\text { Material } \\
\text { Assessment }\end{array}$ & $\%$ & Category \\
\hline Application & 93,46 & Very Good \\
\hline
\end{tabular}

Furthermore, the media expert's assessment provides an assessment of the MC match report application developed and provides suggestions for improvements for further revision. The results of the media expert's assessment of the MC match report application can be seen in table 4 below:

Table 4. Data on the results of the MediaApplication

\begin{tabular}{llcl}
\hline expert & assessment & \% & Category \\
\hline $\begin{array}{l}\text { Expert } \\
1\end{array}$ & Application & 87,45 & Very good \\
\hline $\begin{array}{l}\text { Expert } \\
2\end{array}$ & Application & 86,89 & Very good \\
\hline
\end{tabular}

\section{Individual Trial Results}

Implementation of individual trials was carried out by demonstrating to $6 \mathrm{MC}$ ASKOT PSSI Medan City people who were randomly selected previously as trial people. The process of implementing the feasibility trial of this application uses a demonstration of how the MC Match results report application has been developed, then the MC is given time to operationalize the application as well as mentoring. Then to find out the quality of the developed application, the researcher gave the MC an assessment sheet. During the process of filling out the scoring sheet, the MC can still review the match supervisor report application. In table 5, the results of the MC assessment of the application of the MC results report on the individual trial are presented:

Table 5. Data on the results of the MC assessment of the application in theIndividual Trial

\begin{tabular}{|c|c|c|c|}
\hline MC & & $\%$ & Category \\
\hline Display & & 85,56 & Very Good \\
\hline $\begin{array}{l}\text { Content } \\
\text { Material }\end{array}$ & I & 84,75 & Very Good \\
\hline Use & & 86,85 & Very Good \\
\hline Overall & & 87,75 & Very Good \\
\hline
\end{tabular}

MC assessment of the MC results report application in the display aspect shows a percentage of $85.56 \%$ is in the very good category, in the content / material aspect shows a percentage of $84.75 \%$ is in the very good category, On the aspect of ease of use, it shows a percentage of $86.85 \%$ is in the very good category, and for the overall aspect shows a percentage of $87.75 \%$ is in the very good category. This shows that the MC assessment on the MC ASKOT PSSI report application results in the city of Medan on an individual trial is feasible with improvements in accordance with the suggestions and input, which is then continued with a wider scale trial.

\section{Results of Group Trials The}

implementation of group trials was carried out by demonstrating to 13 MC ASKOT PSSI Medan City who were randomly selected previously as trial people. The process carried out in the trial of the feasibility group for the MC results report application is by demonstrating how the MC match results report application has been developed, then the MC is given time to operationalize the application as well as mentoring. To obtain the quality of the application developed, the researcher provided an assessment sheet to the MC. During the process of filling in the MC scoring sheet, you can also review the 
application of the MC match results report that was done. Table 6 below presents the results of the MC's assessment of the MC match results report in the following group trials.

Table 6. Data Assessment MC on Trial Application Group

\begin{tabular}{|c|c|c|}
\hline MC & $\%$ & Kategori \\
\hline Display & 84,81 & Very Good \\
\hline $\begin{array}{l}\text { Content } \\
\text { Material }\end{array}$ & $/ 86,53$ & Very Good \\
\hline Use & 85,46 & Very Good \\
\hline Overall & 85,76 & Very Good \\
\hline
\end{tabular}

MC's assessment of the MC match results report application in the display aspect of $84.81 \%$ is in the very good category, in the content / material aspect of $86.53 \%$ is in the very good category, in the usage aspect of $85.46 \%$ is in the very category good, and in the overall aspect of $85.76 \%$ it is in the very good category. This shows that MC's assessment of the MC match result report application in the group trial is feasible with the improvements according to the suggestions and can be used as the final product of this study.

\section{Application Improvement}

Improvement of this research product application was carried out 2 (two) times, namely: 1) the first improvement was made in the validation stage, and 2) the second improvement was carried out after the feasibility test of the application. This improvement is based on data from suggestions and input from material experts and media experts. The results of the improvements can be seen in table 7 next. Suggestions and input from this expert validation serve as the basis for researchers to make improvements to the initial product application before conducting individual trials. Researchers review the suggestions and input of experts for improving the developed applications, these suggestions and input are very helpful for researchers as a basis for improving applications that are the product of this research.

Table 7. Suggestions and Feedback from Expert

\begin{tabular}{|c|c|}
\hline Expert & Category \\
\hline Matter & $\begin{array}{l}\text { Already according to } \\
\text { reference; } \\
\text { - Add a recap of the number } \\
\text { of goals scored by players; } \\
\text { - Add red card recap and } \\
\text { yellow card to see which } \\
\text { team is fairest play; and } \\
\text { - In the future, applications for } \\
\text { referee inspectors, referees } \\
\text { and assistant referees will } \\
\text { also be made. }\end{array}$ \\
\hline Media 1 & $\begin{array}{l}\text { The use of color in the } \\
\text { application is less attractive } \\
\text { The writing on the } \\
\text { application should not be too } \\
\text { small; and } \\
\text { - Connecting between the } \\
\text { Player Name List (DNP) } \\
\text { input by the club, the List of } \\
\text { Players (DSP) in the MC } \\
\text { content; }\end{array}$ \\
\hline Media 2 & $\begin{array}{l}\text { Color combination must be } \\
\text { attractive } \\
\text { - Username for logging in the } \\
\text { List of Players (DNP), use } \\
\text { the club email; and } \\
\text { - Connecting between the } \\
\text { validity of the data with the } \\
\text { DNP as well as the DSP. }\end{array}$ \\
\hline
\end{tabular}

The second improvement data used is the suggestion and input data used by the researcher obtained after the implementation of individual trials. Suggestions and input data from individual trials obtained by the researcher can be seen in table 8 below:

Table 8. Suggestions and Input Data from Individual Trials

\begin{tabular}{cc}
\hline No & \multicolumn{1}{c}{ Suggestions and Inputs } \\
\hline 1. & $\begin{array}{l}\text { Secepatnya digunakan MC yang ada } \\
\text { di Sumatera Utara; }\end{array}$ \\
\hline
\end{tabular}


2. Very useful application for match devices;

3. Very helpful $\mathrm{MC}$ in carrying out tasks;

Then the researcher continued the group trial after making improvements to the application that was developed based on the suggestions and input of the test person in the individual trial that was completed.

\section{RESULT}

Next, after the draft application design is completed, it is developed and translated into application programming on the Web. The design stage is the stage of preparing an application framework as well as related to its functions. In the MC ASKOT PSSI match results application application, Medan city includes several sections and pages such as: menu page, DNP page, DSP page, match result report page, and match result recapitulation page. At this stage the application is made to the review of material experts and media experts as well as application improvements. An assessment of the application has been developed in the form of an application report on the results of the MC ASKOT PSSI Medan City showing positive results. This application has undergone several revisions from material experts, media experts and has gone through the trial phase.

As deepening and expanding knowledge is research development, developing is the beginning of the word development which means making it more perfect by means, processes or actions to develop. The purpose of development is not to formulate and test theories but to improve existing or non-existent designs or products in solving real problems, where the design or product developed is effective for use anywhere (Sugiono, 2016); (Arisandi, 2013); (Universitas Negeri Malang, 2010); (Darmadi, 2019); (Nurkadri, 2019). The development of the
MC results report application is based on a needs analysis, namely to help facilitate the MC ASKOT PSSI Medan city, the football club and the interests of the Medan city ASKOT. This need is in accordance with the results of a field survey by distributing questionnaires to 23 MCs ASKOT PSSI Medan City, 100\% can operate a laptop, $82.61 \%$ have never used the MC application from PSSI, for $100 \%$ of the matches held by ASKOT PSSI Medan using reports MC for smooth and professional matches, $100 \%$ of $\mathrm{MC}$ requires a match report application, and $100 \% \mathrm{MC}$ agrees with the development of the match report application.

Based on these data, an application for the MC ASKOT PSSI results report was developed in Medan. The development of this application is a product that is feasible for the $\mathrm{MC}$ ASKOT PSSI Medan city as a report on the results of a soccer match and a musthave for ASKOT PSSI Medan. Making it easier for the management of soccer match equipment in the city of Medan. Similar to the statement the use of such technology with a suitable user interface will empower the coach to gain insight into existing performance levels more readily and conveniently the use of such technology with a suitable user interface will empower the coach to gain insight into existing performance level more readily and conveniently (Pope III et al., 2009). It is concluded that the use of technology in the game of soccer provides flexibility and convenience to the match equipment in increasing ability easily, precisely and efficiently. Next explained that the use of multimedia facilitates and makes all work easier (Fitriadi \& Rachman, 2014).

The MC ASKOT PSSI results report application for Medan city consists of several main menus, namely: first the Player Name List (PNL), the second home menu the Player Composition List (PCL), the three home menuMC report home 
menus, and the fourth an application to recap the results of matches and players. So based on the results of the assessment of material experts and media experts, improvements, individual trials and group trials, the development of the MC ASKOT PSSI results report application in Medan, it can be concluded from the results obtained that this application is feasible to use. So that in the future there will be a match device report application that makes it easier to carry out football matches.

\section{CONCLUSION}

The results of the analysis of needs analysis and data analysis of expert assessments and mc askot pssi medan city, that the steps to develop the application of the askot pssi mc medan results report application, namely starting from stage 1, conducting a preliminary study, gathering information, and designing; stage 2 development and modeling, expert validation and revision, individual trials and revisions, group trials and final products.

Furthermore, this mc application has several menus such as: 1) PNL home menu, 2) PCL home menu, 3) MC report home menu, and 4) match results and player recap application. This is indicated by the results of group trials on the display aspect of $84.81 \%$ in the very good category, in the content / material aspect of $86.53 \%$ in the very good category, in the use aspect of $85.46 \%$ it is in the very category. Good, and in the overall aspect of $85.76 \%$ it is in the very good category.

This application is expected to provide benefits to: 1) the development of science can develop other applications for soccer match devices such as referee inspectors and referees, 2) the next research can serve as a guide, 3 ) the ease and efficiency of mc in carrying out their duties as a football match supervisor ball, 4) the implementation of a soccer match held at ASKOT PSSI Medan city, and 5) increasing the human resources of ASKOT PSSI Medan city, namely mc ASKOT PSSI Medan city towards technological developments.

\section{ACKNOWLEDGEMENT}

Researcher would like to thank everyone who was involved in completing this research, especially to: Chancellor of the Universitas Negeri Medan, who funded this research through the Lembaga Penelitian dan Pengabdian Masyarakat (LPPM) Universitas Negeri Medan, chaired by DIPA funds of Universitas Negeri Medan for fiscal year 2020 No. 0445/UN33/KEP/PPL/2020 dated June 15, 2020, Chairman of ASKOT PSSI Medan and his staff who have agreed to collaborate with Universitas Negeri Medan, to all MC ASKOT PSSI Medan City, Dean of FIK Universitas Negeri Medan, Chairman of the Lembaga Pengembangan dan Penjaminan Mutu Pendidikan (LPPMP) Universitas Negeri Medan, and lecturers of FIK Universitas Negeri Medan.

\section{REFERENCES}

Arisandi, D. (2013). Pengertian Pengembangan. 10.

Barreira, D., Garganta, J., Castellano, J., \& Anguera, M. T. (2013). SoccerEye: A Software Solution to Observe and Record Behaviours in Sport Settings. The Open Sports Sciences Journal, 6(1), $47-55$. https://doi.org/10.2174/1875399x013 06010047

Bidikdot.com. (2020). Kegunaan VAR Dalam Sepak Bola, Indonesia Belajar Dari Thailand. In Bidikdot.com.

Darmadi, H. (2019). Pengantar Pendidikan Era Globalisasi: Konsep Dasar, Teori, Strategi dan Implementasi dalam Pendidikan Globalisasi. An1mage. 
Fitriadi, A., \& Rachman, H. A. (2014).

Pengembangan

Multimedia

Pendidikan Jasmani Materi Budaya Hidup Sehat ... Arief Fitriadi, Hari Amirullah Rachman 1. Jurnal Keolahragaan, 2(1), 1-10.

Khuliman, M. T. (2018). Manajemen Organisasi Dan Kompetensi Perwasitan Sepakbola Askot Pssi Kota Semarang Tahun 2018. Universitas Negeri Semarang.

Malasari, C. A., \& Juntara, P. E. (2021). Development Of Basic Gymnastics Course Textbooks For Students Of Physical Education Study Program. Kinestetik : Jurnal Ilmiah Pendidikan Jasmani, 5(1), 120-127. https://doi.org/10.33369/jk.v5i1.1447 8

Munthali, George, N. C., \& Xuelian, W. (2020). A new decade for social changes. Technium social sciences journal, 6, 173-184.

Nurkadri. (2019). Goenrich Basic Technique Model with Playing Approach for a Beginner Tennis Player. 278(YISHPESS), 96-100. https://doi.org/10.2991/yishpess-cois18.2018.24

Prasetyo, Y. (2015). Kesadaran Masyarakat Berolahraga Untuk Peningkatan Kesehatan Dan Pembangunan Nasional. Medikora, 11(2), 219-228. https://doi.org/10.21831/medikora.v1 $1 \mathrm{i} 2.2819$

Rohmat. (2014). Dongkrak Prestasi Olahraga RI Lewat Penguasaan Iptek. SINDONEWS.COM, 1.

Saputro, Budiono. (2017). Manakemen Penelitian Pengembangan (Reseach \& Development) bagi Penyusun Tesis dan Disertasi. Aswaja Pressindo.

Saputro, Budiyono. (2017). Manajemen Penelitian Pengembangan (Research \& Development) bagi Penyusun Tesis dan Disertasi. In Journal of Chemical Information and Modeling. Aswaja
Pressindo.

Solntsev, I., \& Osokin, N. (2018). Designing a performance measurement framework for regional networks of national sports organizations: evidence from Russian football. Managing Sport and Leisure, 23(1-2), $7-27$. https://doi.org/10.1080/23750472.20 18.1452628

Sugiono. (2016). Metode Penelitan Kuantitatif, kualitatif dan R\&D. Bandung: Alfabeta.

Sugiono. (2019). Metodologi Penelitian. Journal of Chemical Information and Modeling.

Supriyono, E. (2018). Pengembangan aplikasi tes keterampilan sepakbola berbasis web Developing web-based soccer skills test application. Jurnal Keolahragaan, 6(1), p 38-47.

Suryabrata, S. (2016). Metode Penelitian (II). RajaGrafindo Persada.

Universitas Negeri Malang. (2010). Pedoman Penulisan Karya Ilmiah. In Pedoman (Edisi keli, hal. 3). Universitas Negeri Malang. 